\title{
CON SOLO CINCO MIRADAS Segundo Puesto \\ en el Concurso literario UMCH 2016
}

\author{
Maricielo Silva Solís \\ Estudiante de Psicología de la UMCH
}

-Mamá, icuánto me quieres? -le pregunté.

-Muchísimo -y me miró-. iPor qué será que tu hermano nunca quiere ordenar su habitación? ¿Acaso le es tan difícil hacerlo? En ciertas ocasiones no se comporta como yo quisiera. Sin embargo, tú sabes que pase lo que pase yo siempre estaré pendiente de él.

-Mamá, iestás orgullosa de mí?

-Claro que sí -y me miró-. Ya estoy harta de que tu padre deje sus zapatos en el comedor. No sé por qué lo sigue haciendo. Él sabe muy bien que odio eso. No le interesa lo que diga sobre sus "costumbres familiares". Pero es que son tan extrañas e innecesarias que siempre insisto en que las vaya olvidando día a día. De todas formas, yo lo amo y por eso no me gusta discutir con él.

-Mamá, ¿cuántas veces has llorado por mis travesuras?

-Algunas veces -y me miró-. La otra vez escuché a tu hermana gritando. Subí rápidamente las escaleras y felizmente no era nada. Afortunadamente nada de qué preocuparse. Sabes que le fascina el rock. Yo no tengo nada en contra de sus gustos, pero ella siente que no la comprendo y llama a mis baladas música anticuada. No me agrada que se exprese así. iTan solo tiene doce años! Y aunque ella sienta que soy una anciana, yo la amo con toda mi alma.

-Mamá, ¿yo te importo?

-Por supuesto que sí -y me miró-. Tu hermana mayor sigue empecinada en que su novio no la quiere de verdad. Llora todos los días y piensa que él terminará con ella muy pronto. Cuando quiero conversar con ella al respecto no se digna a escucharme. Piensa que mis consejos no la ayudarán pues, según ella, nadie la puede entender. Si supiera que yo también he pasado por esa clase de inseguridades. Que la amo tanto que daría lo que fuera por verla reír.

-Mamá, itú me abandonarías?

-Jamás -y me miró-. Me urge una chica de servicio. Ya no puedo con la limpieza 
yo sola. La casa es muy amplia, las necesidades aumentan y el dinero desaparece cada vez más. Ya ni veo a mis amigas, pero eso no importa tanto. Mi familia vale muchísimo más.

Toda esta conversación se la compartí a mi mejor amigo del colegio. Pero a él no le gustó tanto como a mí.

-No te entiendo -le dije-. ¿Qué es lo que no comprendes?

-iTodo, absolutamente todo! Lo único que sé es que tu mamá respondió todas tus preguntas brevemente y prosiguió con otras respuestas que no tenían ningún sentido.

-Bueno, es lamentable que no lo entiendas -le respondí y regresé al aula.

No obstante, después de reflexionar, mientras venía camino a casa, me di cuenta de que en realidad mi amigo tenía la razón. Las respuestas de mi mamá no tenían mucho sentido, si las tomabas tan literalmente. Pero sí había un sentido, si interpretaba sus palabras como yo las interpreté.

También me di cuenta aquella tarde de que mi amigo no logró entender mi conversación con mi madre por dos razones específicas:

La primera, porque olvidé comentarle que lo último que le dije a mi mamá fue:

-Mamá, tú sufres mucho y yo lo sé. No porque de tus ojos estén cayendo lágrimas, sino porque ellos me transmiten una sensación especial. Si quieres yo puedo ayudarte y no importa si luego llego a agotarme como tú. No importa que te desahogues conmigo a veces, pues yo sé que tú lo necesitas. No importa nada, porque nada vale más que tu mirada. Mamá, iqué transmite tu mirada?

Recuerdo que mamá respondió llorando:

-No sé qué transmite mi mirada, hijita, y tú tampoco. Pero lo que sí sé es que de algún modo tú la entiendes, y eso me llena de felicidad -Luego sonrió y me abrazó fuerte.

Y la segunda razón por la que mi mejor amigo no comprendió todo este capítulo de mi vida fue porque al momento de contárselo olvidé decirle que cuando mamá respondió mis preguntas ella me miró. Es por eso que, cuando continuó contándome otras cosas que no eran correspondientes a lo que yo le había consultado, no le dije nada más. Porque cuando mamá me miraba, sus ojos me aseguraban que sus cortas respuestas eran verdaderas. Sus cinco miradas, de las cinco preguntas que le hice, fueron inolvidables para mí. Y desde mi infancia hasta ahora no he podido explicarme cómo fue que con sus ojos, me bastaron sus palabras.

Mi madre siempre fue muy especial y lo sigue siendo. Porque con tan solo cinco miradas me hizo sentir muy amada. Uno nunca puede entender a su madre con palabras y frases solamente. Uno las comprende y las ama con cada una de sus profundas miradas. 